\title{
PELAKSANAAN PENIMBANGAN DALAM JUAL BELI BUAH KELAPA SAWIT DALAM TINJAUAN HUKUM POSITIF DAN FIQH MUAMALAH (Studi Kasus di Nagari Talao Sungai Kunyit Kecamatan Sangir Balai Janggo Kabupaten Solok Selatan)
}

\author{
Randi Yohari ${ }^{1}$, Eficandra², Afrian Raus ${ }^{3}$ \\ 1Institut Agama Islam Negeri Batusangkar \\ e-mail: randiyohari@gmail.com \\ 2Institut Agama Islam Negeri Batusangkar \\ e-mail: eficandra@iainbatusangkar.ac.id \\ 3Institut Agama Islam Negeri Batusangkar \\ e-mail: afrianraus@iainbatusangkar.ac.id
}

\begin{abstract}
This study aims to explain the implementation of weighing oil palm fruit in Nagari Talao Sungai Kunyit in terms of positive law and figh muamalah. This research is a field research. Data were obtained in two ways, namely secondary data and primary data. The primary data are toke (collectors), oil palm farmers and the Head of the Cooperative and Industry Office of South Solok Regency, while the secondary data sources are the profile of Nagari Talao Sungai Kunyit, Nagari year-end reports and Indonesian legislation. This study found that the implementation of weighing in the sale and purchase of oil palm fruit in Nagari Talao was carried out with containers made of wood that were rarely arranged, so that many "brondol" (small) palm fruit fell. Oil palm fruit that falls from the container is not counted in the scales, as a result of farmers' losses. In fact, the number of "brondol" (small) palm oil that has fallen is quite a lot. In positive law, the implementation of weighing selling oil palm fruit in Nagari Talao is not in accordance with the provisions of Article 25 and Article 28 of Law Number 2 of 1981 concerning Legal Metrology, Article 2 of the Minister of Home Affairs Number 68 of 2018 concerning UTTP Calibration and Re-calibration and Article 8 of Law -Law Number 8 of 1999 concerning Consumer Protection. In this explanation, it is explained that the weighing in buying and selling will not harm either party and the scales used must be recalibrated once a year. As for the implementation of figh muamalah muamalah in Islam, namely injustice to fellow bumans, and there is no fraud (gharar) and elements of coercion (al-ikrah).
\end{abstract}

Keyword: Penimbangan, Jual Beli, Brondol, Fiqh Muamalah

\section{PENDAHULUAN}

$\mathcal{H}$

ukum Islam mengatur kehidupan manusia secara holistik, mencakup segala aspek salah satu aspek utama dalam Islam yaitu jual beli. Jual beli merupakan perjanjian tukar menukar benda atau barang yang memiliki nilai, secara sukarela diantara kedua belah pihak sesuai dengan perjanjian yang disepakati atau ketentuan yang telah ditetapkan syara. (Suhendi, 2002: 69) Prinsip jual beli didasarkan pada suka sama suka dan terbebas dari penipuan dan pengkhianatan. Dengan demikian, dibolehkannya jual beli untuk mempermudah manusia dalam kesulitan ber-muãmalah dengan hartanya. (Syarifuddin, 2005: 194)

Dengan demikian, kepercayaan dan kejujuran merupakan modal dasar dalam transaksi jual beli. Untuk membangun kepercayaan itu seorang pedagang harus mampu berbuat jujur dan adil, baik terhadap dirinya maupun terhadap orang lain. Bukti kejujuran dan keadilan dalam jual beli yaitu adanya nilai timbangan dan ukuran yang tepat yang 
harus diutamakan, maka kepercayaan pembeli kepada penjual akan tercipta dengan sendirinya.

Salah satu praktek jual beli adalah dilakukan dengan cara penimbangan dan salah satu jenis timbangan yang sering digunakan dalam jual beli seperti timbangan gantung. Fungsi dari timbangan gantung sebagai alat untuk mengukur berat beban suatu barang, dengan cara barang tersebut digantung pada pengait timbangan. Barang yang biasa ditimbang dengan timbangan gantung merupakan barang dengan beban terberat, seperti buah kelapa sawit, dan lain-lain. Baik penjual maupun pembeli memakai timbangan gantung untuk menimbang berat buah kelapa sawit. Buah kelapa sawit yang ditimbang bukanlah dalam ukuran sedikit, maksudnya pertandan, namun dalam ukuran banyak yang terdiri dari beberapa tandan. (Ali, 2003: 284)

Pada transaksi jual beli sawit, petani sawit menjual hasil panen buah kelapa sawitnya kepada pembeli (toke) dengan mengikuti harga yang ditentukan pasar. Penimbangan buah kelapa sawit mtidak dilakukan di kebun sawit milik petani, tetapi penimbangan dilakukan di tempat penampungan buah kelapa sawit milik pembeli dengan sebelumnya buah kelapa sawit tersebutsudah diangkut kelokasi penimbangan. Penimbangan dilakukan sendiri oleh pembeli, baik dengan adanya kehadiran penjual maupun tidak dilokasi penimbangan sawit.

Salah satu permasalahan yang sering terjadi dalam transaksi jual beli, yang pada umumnya terjadi adalah alat yang digunakan sebagai alat takar dan timbangan tidak sesuai dengan ketentuan perundang-undangan. Seperti alat takar dan timbangan yang tidak di tera, wadah yang tidak layak untuk menampung barang timbangan dan sebagainya. Perbuatantersebut termasuk tindak pidana (kejahatan dan pelanggaran) yang diatur dalam Undang-undang Nomor 2 Tahun 1981 tentang Metrologi Legal dan Undangundang Nomor 8 Tahun 1999 tentang Perlindungan Konsumen. Pelanggaran yang terjadi pada saat penimbangan buah kelapa sawit khususnya penggunaan wadah timbangan yang tidak layak untuk menampung barang yang akan ditimbang.

Dalam UU Nomor 2 Tahun 1981 tentang Metrologi Legal, Pasal 12disebutkan bahwa, alat perdagangan berupa meteran, anak timbangan, timbangan sentisimal, timbangan meja, takaran kering dan basah, dacin logam, neraca, kuadran surat, timbangan bobot ingsut dan timbangan cepat(digital) harus ditera ulang. Di dalam pasal 20 UU No. 2 Tahun 1981 tentang Metrologi Legal juga membahas tentang :

1. Tanda sah dibubuhkandan atau dipasang pada alat-alat ukur, takar, timbang dan perlengkapannya yang disahkan pada waktu ditera atau ditera ulang.

2. Tanda batal dibubuhkan pada alat-alat ukur, takar, timbang dan perlengkapannya yang dibatalkan pada waktu ditera atau ditera ulang.

3. Tanda jaminan dibubuhkan dan atau -alat ukur, takar, timbang atau perlengkapannya yang sudah disahkan untuk mencegah penukaran dan atau perubahan.

4. Tanda daerah dan tanda pegawai yang berhak dibubuhkan pada alat-alatukur, takar, timbang atau perlengkapannya, agar dapat diketahui dimana dan oleh siapa peneraan dilakukan.

5. Tanda sah dan tanda batal yang tidak mungkin dibubuhkan pada alat- alat ukur, takar, timbang dan perlengkapannya diberikan surat keterangan tertulis sebagai penggantinya. 
Adapun jenis-jenis timbangan yang diperbolehkan oleh Undang- Undang Nomor 2 Tahun 1981 tentang Metrologi Legal, Permendag No. 67/M.DAG/PER/2018 sebagai berikut:

1. Timbangan Otomatis

2. Timbangan bukan otomatis

a. Timbangan bukan otomatis yang penunjukannya otomatis;

b. Timbanbangan bukan otomatis yang penunjukannya semi otomatis (Timbangan Cepat Meja)

c. Timbangan bukan otomatis yang penunjukannya bukan otomatis; (lampiran Permendag Nomor 67/M.DAG/PER/2018)

Adapun dalam Permendagri Nomor 67 tahun 2018 tentang alat-alat ukur, takar, timbang, perlengkapan yang wajib ditera dan ditera ulang. Di dalam ketentuan Pasal 2 Permendagri tersebut UTTP digolongkan kedalam dua golongan:

a. UTTP wajib ditera ulang

b. UTTP bebas ditera dan ditera ulang

Berdasarkan Undang-Undang Nomor 2 Tahun 1981 tentang Metrologi Legal terdiri atas dua kategori yaitu kejahatan dan pelanggaran. Jenis sanksi yang dikategorikan dalam kejahatan terdapat dalam ketentuan Pasal 25, Pasal 26 dan Pasal 27 didalam pasal tersebut dijelaskan bahwa sistem sanksi/ pemidanaan bagi para pelaku yaitu memakai sistem komulatif denda dan pencabutan. Sedangkan dalam kategori pelanggaran yang terdapat dalam ketentuan Pasal 22, Pasal 23, Pasal 30 dan Pasal 31 dijelaskan bahwa sistem sanki/pemidanaan bagi para pelaku yaitu memakai sistem absorsi.

Berdasarkan Undang-Undang Nomor 8 Tahun 1999 tentang Perlindungan Konsumen, ada 10 larangan bagi pelaku usaha sesuai dengan ketentuan Pasal 8 Ayat 1 Undang-Undang Nomor 8 Tahun 1999 tentang Perlindungan Konsumen, tetapi yang berkaitan dengan penggunaan alat takar dan timbangan ada 3 (tiga) dapat diketahui yaitu: 1. Pelaku usaha dilarang memproduksi dan/atau memperdagangkan barang dan/atau jasa yang tidak memenuhi atau tidak sesuai dengan standar yang dipersyaratkan dan ketentuan peraturan perundang- undangan.

2. Tidak sesuai dengan berat bersih, isi bersih atau netto, dan jumlah dalam hitungan sebagaimana yang dinyatakan dalam label atau etiket barang tersebut; dan

3. Tidak sesuai dengan ukuran, takaran, timbangan dan jumlah dalam hitungan menurut ukuran yang sebenarnya.

Pelanggaran terhadap ketentuan tersebut di atas dapat dikenakan sanksi pidana sesuai dengan Pasal 62 Ayat 1 Undang-Undang Nomor 8 Tahun 1999 tentang perlindungan Konsumen berbunyi, pelaku usaha yang melanggar sebagaimana dimaksud dalam ketentuan Pasal 8, Pasal 9, Pasal 10, Pasal 13 Ayat 2, Pasal 15, Pasal 17 Ayat 1 huruf $a$, huruf $b$, huruf $c$, huruf e, Ayat 2 dan Pasal 18 dipidana dengan pidana penjara paling lama lima tahun atau dipidana denda paling banyak Rp. 2.000.000.000,00 (dua miliyar rupiah).

Perlindungan konsumen khususnya terhadap pelaku usahaperkebunan kelapa sawit antara pihak pembeli dan penjual harus ada pengawasan dari pemerintah, terkhususnya pemerintah Provinsi Sumatera Barat memiliki perkebunan kelapa sawit yang cukup luas, perkebunan kelapa sawit saat ini telah berkembang sangat pesat tidak saja diusahakan 
oleh negara tetapi diusahakan juga oleh pihak swasta dan rakyat, sampai tahun 2013 luas area perkebunan rakyat 170.093 ribu Ha. Perkebunan negara seluas 7.836 ribu $\mathrm{Ha}$, dan perkebunan swasta seluas 166.423 ribu Ha yang tersebar di beberapa kabupaten, seperti Kabupaten Solok Selatan. (BPS Provinsi Sumatera Barat, tahun 2013)

Berdasarkan observasi awal, terhadap salah seorang petani yang menjual buah kelapa sawit ke salah seorang pembeli (toke). Adapun praktek jual beli buah kelapa sawit yang dilakukan oleh masyarakat dengan cara dijemput langsung oleh pembeli (toke) kelokasi perkebunan si penjual kemudian dibawa ke tempat penimbangan. Proses penimbangan dilakukan dengan cara meletakkan buah kelapa sawit pada keranjang sebagai wadah timbangan yang berongga jarang, sehingga banyak buah kelapa sawit tersebut berjatuhan "brondol" (kecil) dan tidak masuk dalam hasil timbangan. Salah seorang petani tersebut menjual buah kelapa sawitnya ke toke tersebut berjumlah $600 \mathrm{~kg}$ dengan harga Rp 1.340/kg. Jumlah 600 kg tersebut belum termasuk "brondol" (kecil) yang jatuh pada saat penimbangan berjumlah $15 \mathrm{~kg}$. Berarti jumlah $15 \mathrm{~kg}$ tersebut diluar jumlah $600 \mathrm{~kg}$ secara otomatis dimiliki/ dikuasai oleh pembeli (toke). Ketika penulis tanya lebih lanjut mengenai jumlah "brondol" $15 \mathrm{~kg}$ yang sudah dikuasai oleh toke tersebut, menurutnya hal itu sudah biasa mereka dalam melakukan jual beli buah kelapa sawit, dan petani merasa tidak puasatas hal yang dilakukan oleh pembeli, namun transaki tersebut tetap dilakukan oleh petani dikarenakan tidak ada lagi pembeli yang bisa melakukan proses penimbangan seperti biasanya dan petani kelapa sawit tersebut menyatakan bahwa dari pada sawitnya tidak terjual lebih baik dijualkan saja sama pembeli dan atas apa yang dilakukan oleh pembeli atau pengepul itu itu akan menjadi urusan pengepul atau pembeli tersebut dengan Allah SWT di akhirat nantinya dan tentu kita sebagai petani merasa dirugikan karena pada prinsipnya "brondol" (kecil) tersebut satu kesatuan dengan buah kelapa sawit lainya. (Hasil Observasi, 24 November 2019)

\section{METODE PENELITIAN}

Penelitian ini adalah penelitian lapangan (field research) di Nagari Talao Sungai Kunyit Kecamatan Sangir Balai Janggo Kabupaten Solok Selata. Sumber Data yang penulis lakukan ada 2 yaiu sumber data primer dan sumber data sekunder. Data primer diperoleh langsung dari sumbernya yaitu kepada toke (pengepul), petani buah kelapa sawit dan Kepala Dinas Koperindag Kabupaten Solok Selatan. Untuk sumber data sekunder Prifil Nagari Talao Sungai Kunyit, Laporan akhir tahun Nagari Talao dan Perundang-undangan Indonesia. Teknik pengumpulan data dilakukan dengan observasi, wawancara dan dokumentasi. Untuk wawancara disusun secara sistematis dan lengkap untuk mengumpulkan data yang dicari Dokumentasi. menggunakan reduksi data, penyajian data, penarikan kesimpulan, serta teknik penjaminan keabsahan data menggunakan triangulasi sumber, yaitu melakukan wawancara dengan beberapa orang yang dijadikan sumber datadengan pertanyaan yang sama

\section{HASIL DAN PEMBAHASAN}

\section{A.Pelaksanaan Penimbangan dalam Jual Beli Buah Kelapa Sawit di Nagari Talao}




\section{Sungai Kunyit Kecamatan Sangir Balai Janggo Kabupaten Solok Selatan}

Transaksi jual beli adalah pemindahan hak milik atas benda yang dilakukan oleh dua orang atau lebih untuk memenuhi kebutuhan masing-masing. Transaksi jual beli buah kelapa sawit dalam pandangan masyarakat Nagari Talao Sungai Kunyit adalah sebuah kegiatan muamalah yang bertujuan untuk memperoleh keuntungan.

Kelapa sawit merupakan salah satu komoditas pertanian yang mempunyai nilai ekonomi yang tinggi yang menghasilkan minyak sebagai bahan makanan. Selain itu, berkebun buah kelapa sawit juga merupakan sumber mata pencarian masyarakat yang berada di Nagari Talao Sungai Kunyit pada umumnya. Transaksi jual beli buah kelapa sawit sudah menjadi kebiasaan bagi masyarakat Nagari Talao Sungai Kunyit, buah kelapa sawit yang di perjualbelikan diperoleh para petani dari hasil panennya sendiri dan para toke memperoleh dari hasil panen petani yang menjual kepadanya. Para petani menjual hasil panennya kepada toke atau petani menjual langsung ke pabrik (pihak perusahaan).

Berdasarkan hasil wawancara penulis dengan pembeli (toke)dan penjual (petani) yang berada di Nagari Talao Sungai Kunyit, awal mula pelaksanaan Pelaksanaan jual beli buah kelapa sawit perkebunan milik masyarakat dilakukan dengan cara menjual langsung ke toke (pengepul) yang telah dihubungi sebelumnya untuk menanyakan harga pasar dan ada juga dijual langsung ke pabrik (perusahaan perkebunan sawit). Adapun tempat penimbangan buah kelapa sawit milik masyarakat dilakukan dengan dua cara, yaitu:

1. Dijemput langsung oleh toke (pengepul) ke lokasi perkebunan kelapa sawit milik masyarakat;

2. Diantar langsung oleh penjual ke tempat penampungan milik toke (pengepul).

Jika buah kelapa sawit dijemput ke lokasi terjadi perbedaan harga dengan penimbangan yang dilakukan di tempat penampungan toke (pengepul), apabila penimbangan dilakukan di lokasi perkebunan harganya Rp. 1.200.-, kalau diantar langsung ke penampungan toke (pengepul) harganya Rp. 1.250.-/ Kg, ketentuan ini berbeda-beda setiap toke (pengepul). (Hasil wawancara dengan Bapak Abas selaku toke (pengepul), 26 maret 2020)

Lebih lanjut toke (pengepul) tersebut menerangkan bahwa timbangan yang digunakan adalah timbangan gantung atau dacin berkapasitas $110 \mathrm{~kg}$ dengan wadah yang terbuat dari kayu yang tersusun jarang sebesar $\pm 5 \mathrm{~cm}$. Kemudian setiap kali penimbangan dilakukan pemotongan $10 \mathrm{~kg}$ pemotongan ini didasarkan pada berat wadah timbangan yang terbuat dari kayu yang tersusun jarang. (Hasil Wawancara dengan Bapak Buyung selaku toke (pengepul), 22 Maret 2020)

Keterangan dari salah seorang toke menyatakan bahwa bentukpenimbangan kelapa sawit dengan menggunakan timbangan gantung atau dacin dengan memakai keranjang berongga jarang. Pada setiap penimbangan dipotong $10 \mathrm{~kg}$ dengan dalih berat kotor keranjang tersebut. Adapun buah kelapa sawit "brondol" (kecil) tidak termasuk dalam hitungan toke (pengepul) karena buah kelapa sawit "brondol" (kecil) tersebut terlalu sedikit dan apabila dikumpulkan akan memperlambat proses penimbangan oleh toke (pengepul). Kemudian setelah buah kelapa sawit tersebut selesai ditimbang toke (pengepul) akan menjual lagi ke Pabrik PT. TKA atau PT. KSI dengan perantara atau melalui toke (pengepul) yang mempunyai izin dari perusahaan atau para pemegang delivery order. (Hasil Wawancara dengan Bapak Rauh Putra selaku toke (pengepul), 26 


\section{Maret 2020)}

Keterangan lebih lanjut juga hampir sama apa yang diterangkan oleh toke (pengepul) sebelumnya bahwa buah kelapa sawit yang sudah ditimbang tersebut dipotong $7 \%$ sebelum diberikan hasil bersih kepada penjual atas dasar hasil buah kelapa sawit tersebut akan dijual kembali ke pabrik (perusahaan) dan pabrik (perusahaan) juga melakukan penimbangan ulang dengan pemotongan $5 \%$ dari keseluruhan jumlah berat sawit, analisa pihak pabrik (perusahaan) adalah $5 \%$ tersebutdimasukkan ke berat tandan sawit dan kandungan air yang dimiliki oleh buah kelapa sawit tadi. Jadi bagi kami sebagai toke (pengepul) dasar $2 \%$ dari $7 \%$ pemotongan waktu penimbangan ditempat penimbangan awal tadi itulah sebagai untung atau laba bagi toke (pengepul) (wawancara dengan pembeli, Bapak Abas, 26 maret 2020)

Kemudian bentuk pembayaran hasil timbangan tersebut yaitu setelah buah kelapa sawit tersebut dijual kembali ke pabrik (perusahaan) dari hasil penjualan tersebutlah toke (pengepul) akan membayarkan uang masyarakat sebagai penjual dan ada juga setelah buah kelapa sawit ditimbang oleh toke pada saat itu juga langsung dibayarkan (hasil wawancara dengan Bapak Mizar selaku toke(pengepul), 27 maret 2020).

Kemudian penulis melakukan wawancara dengan beberapa orang petani kelapa sawit tentang pelaksanaan penimbangan dalam jual beli buah kelapa sawit dan mengatakan bahwa dirinya telah dirugikan hal ini berdasarkan keterangan dari salah seorang petani menerangkan bahwa:

"Pernah suatu ketika saya problem tentang penimbangan buah kelapa sawit karena hasil panen tidak sesuai jumlahnya setelah ditimbang oleh toke. Pada saat itu saya pernah dibilang sama toke (pengepul), kalau Ibuk komplen sama saya, silahkan cari saja toke (pengepul) lain yang bisa jemput buah kelapa sawit Ibuk kelokasi yang sangat susah untuk dijangkau itu, mendengar hal tersebut saya cuma bisa diam karena tidak tau akan berbuat apa, dari pada tidak terjual biarlah rugi sedikit karena hal itu sudah menjadi kebiasaan" tuturnya (Hasil wawancara dengan Ibuk Nurbaiti selaku penjual, Selasa 24 Maret 2020)

Penjual lainya juga menerangkan hal yang sama bahwa:

"Waktu saya tanya kepada toke (pengepul), jawabnya karena buah yang jatuh pada saat penimbangan tersebut terlalu sedikit dan akan memperlambat pekerjaan toke (pengepul), padahal dalam hati saya berpikir buah yang jatuh tersebut masih banyak keuntungan bagi saya sebagai penjual karena buah kelapa sawit "brondol" (kecil) tersebut termasuk hasil yang dipanen dari kebun dan masih bernilai uang, saya malas ribut sama toke (pengepul) tersebut karena sayamasih ada hutang sama toke (pengepul) tersebut. Tuturnya (Hasil wawancara dengan Bapak Syafril selaku penjual, Kamis 19 Maret 2020)

Berdasarkan wawancara yang penulis lakukan dengan toke(pengepul) dan penjual tentang pelaksanaan penimbangan dalam jual beli buah kelapa sawit di Nagari Talao Sungai Kunyit Kecamatan Sangir Balai Janggo Kabupaten Solok Selatan bahwasannya telah terjadi proses penimbangan buah kelapa sawit yang menggunakan timbangan gantung (dacin) yang dilakukan dengan wadah yang terbuat dari kayu yang tersusun jarang yang memiliki jarak $5 \mathrm{~cm}$. Sehingga buah kelapa sawit "brondol" (kecil) banyak yang berjatuhan. Buahkelapa sawit "brondol" (kecil) yang jatuh pada saat penimbangan menjadi hak milik toke, alasan toke tidak menilai buah sawit "brondol" (kecil) yang jatuh pada saat penimbangan karena pengumpulan setiap "brondol" (kecil) yang jatuh menghabiskan waktu yang lama sehingga terlambatnya toke melakukan penjualan buah 
kelapa sawit ke pabrik (pihak perusahaan). Menurut penulis pelaksanaan penimbangan dalam jual beli buah kelapa sawit tersebut terdapat pihak yang dirugikan yaitu petani sawit karena pada saat penimbangan buah kelapa sawit "brondol" (kecil) tidak termasuk dalam hitungan toke padahal jumlah buah kelapa sawit "brondol" (kecil) mempunyai jumlah yang cukup banyak.

\section{B. Pandangan Hukum Positif dan Fiqh Muamalah terhadap proses penimbangan jual beli buah kelapa sawit di Nagari Talao Sungai Kunyit Kecamatan Sangir Balai Janggo Kabupaten Solok Selatan}

\section{Pandangan Hukum Positif terhadap Proses Penimbangan Jual Beli Buah Kelapa Sawit di Nagari Talao Sungai Kunyit.}

Berdasarkan Undang-Undang Nomor 2 Tahun 1981 tentang Metrologi Legal dan Undang-Undang Nomor 8 Tahun 1999 tentang Perlindungan Konsumen, bahwa perbuatan yang merugikan salah satu pihak dalam jual beli merupakan tindak pidana (kejahatan dan pelanggaran).

Ketentuan mengenai perbuatan yang dilakukan oleh toke (pengepul) dengan penjual yang merugikan salah satu pihak yang diatur dalam Undang-Undang No. 2 Tahun 1981 tentang Metrologi Legal yang dijelaskan dalam Pasal 25 huruf a dan huruf e menjelaskan bahwa larangan ini bertujuan untuk melindungi agar tidak ada pihak yang dirugikan akibat dari pemakaian alat-alatukur, takar, timbangan atau perlengkapannya yang tidak memenuhi kebenaran, kepekaan dan ketepatan penunjukannya. Pasal 28 Huruf c juga menjelaskan sifat dan kemampuan untuk dapat memberikan pelayanan yang benar dan dalam batas-batas kesalahan yang diizinkan terhadap penggunaan UTTP perlu ditaati agar dalam pemakaian tidak merugikan pemakai atau pihak yang dilayani oleh pihak tersebut.

Ketentuan mengenai sanksi atas kejahatan dan atau pelanggaran dalam hal jual belli diatur dalam ketentuan Undang- Undang Nomor 2Tahun 1981 tentang Metrologi Legal yang diatur dalam Pasal 32 sebagai berikut:

a. Pasal 32 ayat 1 bahwa, barang siapa melakukan perbuatan yang tercantum dalam Pasal

25, Pasal 26, Pasal 27, dan Pasal 28 Undang-undang ini dipidana penjara selamalamanya 1 (satu) tahun dan atau denda setinggi-tingginya Rp. 1.000.000,- (satu juta rupiah).

b. Pasal 32 ayat 2 bahwa, barang siapa melakukan perbuatan yang tercantum dalam Pasal 30 dan Pasal 31 Undang-undang inidipidana penjara selama-lamanya 6 (enam) bulan dan atau denda setinggi-tingginya Rp. 500.000,-(lima ratus ribu rupiah).

c. Pasal 33 ayat 1 bahwa, perbuatan sebagaimana yang dimaksud dalam Pasal 32 ayat 1 dan ayat 2 undang-undang ini adalah kejahatan.

d. Pasal 33 ayat 3 bahwa, Barang yang menjadi bukti kejahatan dan atau pelanggaran dapat dirampas untuk kepentingan Negara.

Ketentuan dari Undang-Undang No 2 Tahun 1981 tentang metrologi telah menjelaskan bahwasanya pelaksanaan penimbangan dalam jual beli kelapa sawit telah melanggar ketentuan Pasal 25 huruf a dan huruf e dan 28 huruf c. Hal ini tidak ada pengawasandari Dinas Koperindag Kabupaten Solok Selatan selaku yang mengawasi di Nagari Talao Sungai Kunyit karena anggaran dari solok selatan tidak mencukupi untuk 
melakukan peneraan ulang terhadap timbangan serta pejabat khusus yang melakukan peneraan ulang yang di-SK-kan oleh Kementrian Perdagangan RI juga belum ada dan jika Dinas Koperindag Kabupaten Solok Selatan ingin melakukan tera ulang pejabat khususnya bisa didapatkan dengan cara bekerja sama dengan Dinas Koperindag Kota Solok.

Menurut Permendagri Nomor 68 Tahun 2018 tentang tera dan tera ulang alat-alat ukur, takar, timbang dan perlengkapannya, di dalam ketentuan Pasal 2 menjelaskan bahwa:

a. Kegiatan tera dan tera ulang meliputi pemeriksaan, pengujian dan pembubuhan tanda tera;

b. Pemeriksaan dan pengujian dilakukan terhadap UTTP sebelum dibubuhi tanda tera ;

c. Pengujian terhadap UTTP dilakukan dengan menggunakanstandar ukuran yang telah tertelusur;

d. Pemeriksaan, pengujian, dan pembubuhan tanda tera dilakukan berdasarkan syarat teknis alat ukur, takar dan alat timbang;

Berdasarkan penjelasan pasal diatas bahwa timbangan yang sudah habis masa berlakunya wajib ditera ulang lagi oleh Dinas Koperindag Kabupaten Solok Selatan, namun realita yang terjadi di Nagari Talao Sungai Kunyit berdasarkan penelitian penulis para toke tidak pernah melakukan peneraan ulang timbangan yang dipakainya. Timbangan yang digunakan oleh pihak toke adalah timbangan bukan otomatis yang penunjukannya bukan otomatis yang dibantu sama keranjang yang berongga jarang, dari segi bentuk timbangan yang dipakai oleh pihak toke belum memenuhi kriteria timbang yang sesuai didalam ketentuan Undang-Undang. Dan apabila terjadi suatu konflik antara pihak penjual dan pembeli diselesaikan dengan cara pembeli memberikan pilihan kepada penjual yang tidak akan pernah bisa dipenuhi oleh pihak penjual.Hal ini juga terdapat dalam transaksi jual beli dalam ajaran Islam yang dinamakan dengan khiyar. Khiyar menurut Kompilasi Hukum Ekonomi Syariah dalam ketentuan Pasal 20 Ayat 8 adalah hak pilih bagi penjual dan pembeli untuk melanjutkan atau membatalkan akadjual beli yang dilakukannya.

Sanksi yang diberikan kepada toke (pengepul) yang melakukan pelanggaran karena melakukan penimbangan dengan timbangan yang tidak di tera ulang setiap tahunnya maka tidak diperbolehkan untuk melakukan pelaksanaan jual beli yang khususnya pelaksanaan jual beli buah kelapa sawit karena tidak sesuai dengan peraturan perundangundangan dan merugikan salah satu pihak. Namun pemberian sanksi dalam undangundang ini belum terlaksana dengan baik dikarenakan Dinas Koperindag Kabupaten Solok Selatan yang berwenang mengawasi perdagangan belum mempunyai pegawai yang khsusus melakukan pengawasan dibidangtimbangan.

Peraturan Mentri Perdagangan Republik Indonesia Nomor 68 Tahun 2018 tentang alat-alat ukur, takar, timbang dan perlengkapannya dijelaskan dalam ketentuan Pasal 1 Ayat 4 bahwa pegawai yang berhak menera atau menera ulang adalah pegawai negri sipil yang diberi tugas, tanggung jawab, wewenang, dan hak secara penuh oleh pejabat yang berwewenang untuk melakukan peneraan, sedangkan didalam ketentuan Pasal 1 Ayat 3 yang dimaksud dengan tera ulang adalah hal yang menandai berkala dengan tanda tera sah atau tera batal yang berlaku atau memberikan keterangan-keterangan tertulis yang 
tertera tanda sah atau tera batal yang berlaku. Pejabat yang berwewenang melakukan peneraan berhak juga untuk menjustir alat-alat ukur, takar, timbang dan perlengkapannya yang diajukan untuk ditera atau ditera ulang apabila ternyata belum memenuhi syaratsyarat.

Hal inilah yang menyebabkan terjadinya praktek jual beli yang melanggar ketentuan peraturan perundang-undangan dan hukum Islam karena tidak adanya penyuluhan dari pemerintah nagari atau Dinas Koperindag yang mengawasi jual beli yang menggunakan timbangan(Hasil Wawancara dengan Bapak Buyung selaku toke (pengepul), 22 Maret 2020)

Kewenangan pengawasan penimbangan yang dilakukan oleh Dinas Koperindag berdasarkan perintah dari Dinas Koperindag Provinsi Sumbar, karena diatur oleh Undang-Undang Nomor 23 Tahun 2014 tentang Pemerintah Daerah. Tetapi dari awal undang- undang ini berlaku belum pernah ada perintah dari Dinas Koperindag Sumbar kepada Dinas Koperindag Kabupaten Solok Selatan untuk melakukan pengawasan terhadap timbangan yang dipergunakan oleh pembeli dilapangan termasuk salah satunya timbangan dacin yang dipergunakan oleh toke (pengepul) sawit di Nagari Talao Sungai Kunyit. (Hasil wawancara dengan Bapak May Riski, 17 Maret 2020)

Jika dilihat dari hukum positif penggunaan alat timbang yang digunakan oleh toke kelapa sawit di Nagari Talao Sungai Kunyit tidak sesuai dengan ketentuan Pasal 12, Pasal 25, Pasal 28 Undang- Undang Nomor Tahun 1981 tentang Metrologi Legal dan Pasal 2 dan Pasal 3 Permendagri Nomor 68 Tahun 2018 tentang Tera dan Tera Ulang UTTP bahwa timbangan yang sudah lama dipakai harus dilakukan peneraan ulang timbangan dimana alat timbangan yang digunakan oleh toke tidak pernah dilakukan peneraan ulang dan alat bantu yang digunakan oleh toke juga tidak memenuhi kriteria yang mana memakai keranjang yang berongga jarang sehingga brondol berjatuhan pada saat penimbangan dan buah kelapa sawit "brondol" (kecil) yang jatuh tersebut berdasarkan hasil wawancara dengan para toke tidak ditimbang kembali dengan alasan brondol yang jatuh sedikit dan memperlambat kerja toke sedangkan dalam aturan undang-undang berapapun jumlahnya pada saat transaksi jual beli harus dimasukan kedalam hitungan. Terlepas dari itu lembaga yang berwenang melakukan pengawasan dan tera ulang terhadap timbangan dari daerah tersebut tidak efektif, lembaga yang berwenang dalam pengawasan tersebut adalah dinas Koperindag Kabupaten Solok Selatan. Pengawasan yang lebih efektif dilakukan oleh Dinas Koperindag Kabupaten Solok Selatan adalah dilakukan tera ulang timbangan secara rutin.

Dari hasil wawancara dengan salah seorang pegawai Dinas Koperindag Solok Selatan dapat disimpulkan bahwa pengawasan dan tera ulang Dinas Koperindag Kabupaten Solok Selatan masih belum efektif dikarenakan pada awalnya pejabat yang berwenang melakukan pengawasan dan tera ulang terhadap timbangan kelapa sawit dilakukan oleh dinas Koperindag provinsi dan tidak terealisasi dengan baik, hingga pada tahun 2018 adanya ketentuan Permendagri Nomor 68 Tahun 2018 tentang tera dan tera ulang UTTP, yang mana pejabat yang berwenang yang melakukan tera ulang ditugaskan kepada Dinas Koperindag Daerah masing-masing dan dalam hal ini Koperindag Provinsi melimpahkan wewenangnya kepada Dinas Koperindag Kabupaten/kota, namun setelah peralihan wewenang tersebut kepada Dinas Koperindag Kabupaten Solok Selatan 
pelaksanaan pengawasan dan tera ulang masih belum juga efektif dilakukan bahkan untuk melakukan tera ulang terhadap timbangan kelapa sawit belum pernah dilakukan oleh Koperindag Kabupaten Solok Selatan dikarenakan pejabat khusus yang melakukan peneraan ulang yang di SK kan oleh Kementrian Perdagangan RI belum ada. Jika Dinas Koperindag Kabupaten Solok Selatan ingin melakukan tera ulang pejabat khususnya bisa didapatkan dengan cara bekerja sama dengan Dinas Koperindag Kota Solok

Jika dilihat dari undang-undang perlindungan konsumen praktek jual beli buah kelapa sawit di Nagari Talao Sungai Kunyit juga menyalahi aturan Undang-Undang Perlindungan Konsumen Nomor 8 tahun 1999 pada ketentuan pasal 8 poin c yang mana berdasarkan hasil wawancara dengan beberapa penjual kelapa sawit mereka mengatakan bahwa sebenarnya mereka ingin komplen tetapi karna keterbatasan kendaraan dan tidak enak hati, takut toke (pengepul) tersinggung sehingga toke (pengepu) tersebut tidak mau lagi sawitnya penjual (masyarakat), pelaksanaan jual beli yang dilakukan di Nagarai Talao Sungai Kunyit adanya unsur keterpaksaan, selain itu tidak terpenuhinya unsur beritikad baik dalam ketentuan Undang-Undang Perlindungan Konsumen.

\section{Pandangan Fiqh Muamalah Terhadap Proses PenimbanganJual Beli Buah Kelapa Sawit di Nagari Talao Sungai Kunyit.}

Praktik jual beli buah kelapa sawit di Nagari Talao Sungai Kunyit menggunakan timbangan, Allah SWT menegaskan apabila transaksi jual beli menggunakan timbangan mereka berkewajiban untuk memenuhi timbangan dan transaksi jual beli hendaknya atas dasar suka sama suka. Sebagaimana firman Allah dalam Q.S An-Nisa ayat 29; "Hai orangorang yang beriman, janganlah kamu saling memakanharta sesamamu dengan jalan yang batil, kecuali dengan jalann perniagaan yang berlaku dengan suka sama-suka di antara kamu." Dalam Al-Qur'an dijelaskan bahwa dilarang memakan harta sesama secara bathil. Hal ini terdapat dalam Q.S An-Nisa ayat 30; "Dan Barangsiapa berbuat demikian dengan melanggar hak dan aniaya, Maka Kami kelak akan memasukkannya ke dalam neraka. yang demikian itu adalah mudah bagi Allah".

Kandungan didalam ayat diatas sangat jelas menyatakan bahwa ketika penjual dan pembeli ingin melakukan transaksi maka harus suka sama suka dalam kata lain sebuah keputusan dalam jual beli adalah kesepatan berdua atas dasar rihdo sama ridho. Namun dalam praktek jual beli buah kelapa sawit di Nagari Talao Sungai Kunyit berdasarkan wawancara dengan beberapa penjual dan pembeli maka dapat dikatakan bahwa transaksinya tidak sesuai dengan aturan fiqh muamalah yang mana dalam transaksi tersebut ada unsur keterpaksaan (al-ikrah) dari penjual dalam menjual sawitnya kepada pembeli/toke, bentuk dari keterpaksaan penjual dalam hal ini berupa bentuk keranjang timbangan yang berongga jarang dan buah brondol yang berjatuhan dicampurkan dengan sawit yang sudah ditimbang tampa meninbang kembali brondol tersebut. Dalam hal ini penjual merasa dirugikan tetapi proses transaksi tetap dilakukan karna semua toke yang ada di nagari tersebut bentuk timbangan buah kelapa sawit dan cara pelaksanaannya sama.

Untuk mengawasi harta dan menjaga hak perseorangan islammengajak supaya para pedagang senantiasa mengatur takaran dan timbangannya dalam perdagangan secara tepat. Berkaitan dengan ini islam memerintahkan kepada umatnya agar jangan mengurangi takaran dan timbangan yang dijelaskan dalam firman Allah SWT 
diantaranya Q.S Asy-Syu'ara ayat 181-183; "Sempurnakanlah takaran dan janganlah kamu termasuk orang-orang yang merugikan dan timbanglah dengan timbangan yang lurus dan janganlah kamu merugikan manusia pada hak-haknya dan janganlah kamu merajalela di muka bumi dengan membuat kerusakan". Allah juga berfirman dalam Q.S. Al-Isra' ayat 35: "Dan sempurnakanlah takaran apabila kamu menakar, dan timbanglah dengan timbangan yang benar. Itulah yang lebih utama (bagimu) dan lebih baik akibatnya".

Ayat di atas menjelaskan wajib hukumnya untuk menyempurnakan sukatan dan timbangan, karena perbuatan ini akan mengurangi hak orang lain. Ayat tersebut juga memberikan sentilan kepada sekelompok orang yang menipu timbangan dan pada saat menyukat untuk dirinya ia lebihkan. Selanjutnya Allah menegaskan balasan bagi orangorang yang curang dalam timbanga, sebagaimana firman Allah dalam Q.S Al-Muthaffifin ayat 1-6: "Celaka besarlah bagi orang-orang yang curang, (yaitu) orangyang apabila menerima takaran dari orang lain mereka minta dipenuhi, dan apabila mereka menakar dan menimbang untuk orang lain, mereka mengurangi. Tidakkah orang itu yakin, bahwa sesungguhnya mereka akan dibangkitkan, pada suati hari yang besar, (yaitu) hari (ketika) manusia berdiri menghadap Tuhan semesta alam?.

Ayat tersebut memberikan penjelasan bahwa apabila seseorang curang dalam menakar dan menimbang ketika penimbangan dilakukan untuk orang lain mereka selalu mengurangi dan apabila orang melakukan penimbangan untuk dirinya sendiri selalu minta dipenuhi, perbuatan tersebut akan balas oleh Allah SWT di akhirat nanti. Dan pada pelaksanaan penimbangan yang ada di Nagari Talao sungai kunyit sangat jelas bahwa toke dalam menimbang buah kelapa sawit selalu mengambil keuntungan yang lebih, dimana keuntungan tersebut diperoleh dengan menggunakan timbangan yang tidak sesuai dengan ketentuan-ketentuan fiqh muamalah.

Pelaksanaan penimbangan yang dilakukan oleh toke di Nagari Talao Sungai Kunyit tidak memenuhi timbangannya secara adil, para toke tersebut melebihkan timbangan untuk dirinya sendiri dengan caratidak mengumpul kembali brondol yang jatuh pada saat proses penimbangan baik secara sepengetahuan penjual maupun tanpa sepengetahuan penjual (gharar) serta adanya pemaksaan (al-ikrah). Sebagaimana perilaku semacam ini tentu akan menghilangkan sifat kejujuran dalam bermuamalah.

Prinsip jujur adalah dapat dipercaya dalam muamalah yang dilakukan sehingga terhindar dari kedzaliman dan penipuan terhadap salah satu pihak yang melakukan muamalah. Dapat dipercaya berarti konsisten dan konsekuen serta bertanggung jawab dalam bermuamalah. (Mustofa, 2016: 19)

Di samping itu, perlu juga diperhatikan Prinsip muamalah dalam Islam, sebagaimana dikemukakan Ahmad Azhar Basyiri sebagai berikut:

1. Pada dasarnya segala bentuk muamalat adalah mubah, kecuali yang ditentukan oleh alQur'an dan sunnah rasul.

2. Muamalat dilakukan atas dasar sukarela tanpa mengandung unsur paksaan.

3. Muamalat dilakukan atas dasar pertimbangan mendatangkan manfaat dan menghindari mudharat dalam hidup masyarakat.

Didalam transaksi jual beli hendaknya selalu menerapkan prinsip-prinsip yang terhindar dari jual beli yang terlarang yaitunya terhindar dari ketidajelasan atau gharar, terhindar dari prinsip riba danterhindar dari prinsip bathil. Dengan dilakukanya prinsip tersebut maka tidak akan ada antara penjual dan pembeli merasa dirugikan. Dan tidak 
akan ada juga unsur keterpaksaan antara satu pihak dalam melakukan transaksi jual beli khsususnya dalam pelaksanaan penimbangan jual beli buah kelapa sawit di Nagari Talao Sungai Kunyit. Dan pelaksanaan jual beli buah kelapa sawit antara toke (pengepul) dengan penjual (masyarakat) yang sudah menjadi kebiasan tersebut adalah kebiasaan yang dilarang menurut hukum Islam maupun peraturan perundang-undangan karena telah melanggar prinsip-prinsi dalam jual beli (perdagangan) yaitu prinsip kerelaan, keadilan dan kejujuran. Adapun penyuluhan yang harus dilakukan adalah penyuluhan tentang timbangan yang masih layak dipakai dan timbangan yang seharusnya ditera ulang, dan seharusnya pengawasan dilakukan setiap tahun karena berdasarkan UndangUndang tugas dari Dinas Koperindag melakukan pengawasan dan peneraan ulang timbangan sekali setahun.

Berdasarkan ayat Al-Qurean, sunah dan kaidah ushul Fiqih menjelaskan bahwa pelaksanaan penimbangan jual beli buah kelapa sawit yang terjadi di Nagari Talao Sungai Kunyit termasuk memakan harta sesama dengan jalan yang bathil dan melanggar etika dalam bermuamalah dalam Islam, yakninya zalim terhadap sesama manusia, serta adanya unsur penipuan (gharar) dan unsur pemaksaaan (al-ikrah). karena pada waktu penimbangan banyak buah kelapa sawit "brondol" (kecil) sawit yang berjatuhan namun tidak terhitung dalam timbangan.

\section{KESIMPULAN}

Berdasarkan hasil penelitian yang penulis lakukan maka dapat ditarik kesimpulan bahwa: Pelaksanaan Penimbangan dalam jual beli buah kelapa sawit di Nagari Talao Sungai Kunyit Kecamatan Sangir Balai Janggo Kabupaten Solok Selatan adalah penimbangan dilakukan dengan wadah yang terbuat dari kayu yang tersusun jarang, sehingga buah kelapa sawit "brondol" (kecil) banyak yang berjatuhan, buah kelapa sawit yang terjatuh dari wadah tidak tehitung dalam timbangan, akibatnya petani mengalami kerugian. Padahal jumlah brondol yang berjatuhan mempunyai jumlah yang banyak.

Berdasarkan Pasal 25 dan Pasal 28 Undang-Undang Nomor 2 Tahun 1981 tentang Metrologi legal, Pasal 2 Permendagri Nomor 68 tahun 2018 tentang Tera dan Tera ulang UTTP dan Pasal 8 Undang- Undang Nomor 8 tahun 1999 tentang Perlindungan Konsumen bahwapelaksanaan penimbangan buah kelapa sawit di Nagari Talao Sungai Kunyit tidak sesuai dengan ketentuan hukum positif. Berdasarkan ketentuan fiqh muamalah dan prinsip jual beli dalam Islam yang merujuk kepada Al-Qur'an surah AnNisa' ayat 29-30, Surah Al-Isra' ayat 35, dan surah Al-Muthaffifin ayat 1-6, maka proses penimbangan jual beli buah kelapa sawit di Nagari Talao Sungai Kunyit termasuk memakan harta sesama secara bathil, sertaa adanya unsur penipuan (gharar) dan unsur pemaksaan (al-ikrah).

\section{DAFTAR PUSTAKA}

Ahmad. (2003). Etika Bisnis Dalam Islam. Jakarta: Pustaka Al-Kautsar.

Mudjahidin, A. (2007). Ekonomi Islam. Jakarta: PT Raja Grafindo.

Al Jaziri, A. (2015). Fikih Empat Mazhab. Kairo: DarulUlum Pers 
Arianti, F. (2014). Fikih Muamalah II. Batusangkar: STAINBatusangkar Press.

Arianti, F. (2015). Fikih Muamalah I. Batusangkar: STAINBatusangkar Press.

Az-Zuhaili, W. (2011). Fiqih Islam Wa Adilallatuhu. Jilid 7. Jakarta: Gema Insani.

Az-Zuhaili, W. (2011). Fiqih Islam Wa Adilallatuhu. Jilid 5. Jakarta: Gema Insani.

Basyri, A. A. (2000). Asas-asas Hukum Mu'amalat (Hukum Perdata Islam). Yogyakarta: UII Press.

Direktorat Metrologi Bandung. (2006). Sebaiknya Anda Tahu Menimbang dengan Menggunakan Neraca, Daun, Timbangan Meja, Timbangan Senti Semal. Bandung: Direktorat Mentrologi.

Djamil, F. (2001). Hukum Perjanjian Syari" ah. Bandung: CitraAditya Bakti.

Ghazaly, A. R. (2015). Fiqh Muamalah. Jakarta: Prenada Media Group.

Haroen, N. (2000). Figh Muamalah: Jakarta. Gaya Media Pratama.

Hasan, M. A. (2004). Berbagai Macam Transaksi dalam Islam, Jakarta: Raja Grafindi Persada.

Hidayat, E. (2015). Fiqih Jual Beli. Bandung: Remaja Rosdakarya.

Hulwati. (2009). Ekonomi Islam: Teori dan Praktiknya dalam Perdagangan Obligasi Syariah. Ciputat: Ciputat Press Group

Kamus Pintar Kelapa Sawit. Opai.wordPress.com diakses pada tanggal 14Januari 2020 pada jam 10.30 WIB.

Karim, A. \& O. S. (2015). Riba, Gharar, dan Kaidah-kaidah Ekonomi Syariah. Jakarta: PT. Raja grafindo Persada.

Kasmuri, Dkk. (2017). Buku Pedoman Penulisan Skripsi IAIN Batusangkar.Batusangkar: IAIN Batusangkar.

Khosy'ah. (2014). Figh Muamalah Perbandingan: Bandung. Pustaka Setia.

Lubis, S. K. (2000). Hukum Ekonomi Islam. Jakarta: Sinar Grafika.

Mardani. (2013). Fiqh Ekonomi Syariah. Jakarta: Kencana.

Mudjahidin, A. (2007). Ekonomi Islam. Jakarta: PT Raja Grafindo.

Yunus, M. (1990). Kamus arab Indonesia. Jakarta: HidakaryaAgung.

Muslich, A.W. (2010). Figh Muamalat. Jakarta: Amzah

Pasaribu, C. (1996). Hukum Perjanjian dalam Islam. Jakarta: Sinar Grafika.

Salim, P. (1991). Kamus Bahasa Indonesia Kontemporer. Jakarta: Modern Englis Pers

Rachmawati, E. N. A. M. (2015). Jurnal Akad Jual Beli Dalam Perspektif Fikih. Al-Adalah, XII (4): 786

Shobirin. (2015). Jual Beli Dalam Pandangan Islam. Jurnal Bisnis dan Manajemen Islam, 3 (2): 241-241

Sugiyono. (2009). Metode Penelitian Kuantitatif Kualitatif dan RED. Bandung: Alfabeta.

Suhendi, H. (2008). Figh Muamalah: Jakarta. PT Raja Grafindo.

Syafi'i, R. (2004). Fiqih Muamalah. Bandung: Pustaka Setia.

Undang-Undang Dasar Negara Republik Indonesia Tahun 1945

Undang-Undang Nomor 2 Tahun 1981 tentang Metrologi Legal

Undang-Undang Nomor 8 Tahun 1999 tentang Perlindungan Konsumen.

Permendag RI Nomor 68 Tahun 2018 tentang Tera dan Tera Ulang UTTP

Qhordawi, Y. (n.d). Peran Nilai Moral Dalam Perekonomian Islam. Jakarta: Robbani Pers. 